\title{
POULTRY PRODUCTS ENRICHED WITH SELENIUM AND THEIR IMPACT ON HEALTH
}

\author{
Zlata Kralik, Manuela Grčević \\ Faculty of Agriculture in Osijek, \\ Vladimira Preloga 1, 31000 Osijek, Croatia \\ Zlata.Kralik@pfos.hr
}

\begin{abstract}
The paper presents various options of enrichment of poultry products (eggs and meat) with trace element selenium, as well as its impact on human health. Since the eggs and poultry meat are a good sources of protein, amino acids and fatty acids, and their prices are acceptable, they are often used daily in the human diet. By adding selenium in feed, it is possible to increase its content in eggs and muscle tissue of chickens. Regarding the sources of selenium, researchers prefer the organic form of selenium compared to inorganic, because of its better utilization from feed to the body. Addition of organic selenium in feed for animals is important for normal reproductive function (spermatogenesis), better hatchability and better viability of one-day offspring, the oxidative protection of the cells, better immune status of the organism, improved production and quality of eggs and meat. Using poultry products enriched with selenium in human nutrition provides the body with the required amount of selenium and can positively influence the human immune system. Furthermore, the importance of selenium is reflected in its role of catalyst in the production of the active form of thyroid hormone. Selenium is an essential nutrient in response to viral infections and maintenance of reproductive capabilities (better sperm motility and decreased risk of miscarriage). Because of all mentioned, eggs and poultry meat enriched with organic source of selenium have extra nutritional, but also health value for people.
\end{abstract}

Key words: chicken meat; eggs; enrichment; selenium; health

\section{ЖИВИНСКИ ПРОИЗВОДИ ЗБОГАТЕНИ СО СЕЛЕН И НИВНОТО ВЛИЈАНИЕ ВРЗ ЗДРАВЈЕТО}

Во овој труд се презентирани неколку различни опции за збогатување на живински производи (јајца и месо) со селен (елемент во трагови), како и неговото влијание врз човековото здравје. Бидејќ јајцата и месото од живина се добри извори на протеини, аминокиселини и масни киселини и нивната цена е прифатлива, тие често се користат секојдневно во човековата исхрана. Со додавање селен во добиточната храна е можно да се зголеми неговата содржина во јајцата и во мускулното ткиво на кокошките. Во врска со изворите на селен, истражувачите претпочитаат органска форма на селен наместо неорганска, поради неговото подобро искористување од храна во телото. Додавањето на органскиот селен во добиточната храна за животните е важно за нормална репродуктивна функција (сперматогенеза), подобра изведливост и подобра животоспособност на еднодневни пиленца, оксидативна заштита на клетките, подобар имунолошки статус на организмот, како и подобрено производство и квалитетот на јајцата и месото. Употребата на производи од живина збогатени со селен во исхраната на човекот на телото му го обезбедува потребното количество селен и може позитивно да влијае на човечкиот имун систем. Понатаму, важноста на селенот се рефлектира во неговата улога на катализатор во производството на активна форма на тироидниот хормон. Селенот е есенцијална состојка на храна која дејствува врз вирусни инфекции и одржување на репродуктивните способности (подобра подвижност на спермата и намален ризик од спонтан абортус). Од сите овие причини, јајцата и живинското месо збогатени со органски извор на селен имаат посебна нутритивна, но и здравствена вредност за луѓето.

Клучни зборови: живинско месо; јајца; збогатување; селен; здравје 


\section{INTRODUCTION}

Poultry products, meat and eggs, are highly appreciated in the food products market. Poultry meat occupies one of a leading position in the consumption of all types of meat, both in Croatia and in the most developed countries of the world. Eggs represent quality, affordable and inexpensive foodstuff in many countries and cultures. Ten years back in the food market have emerged foods that are enriched with various nutricines and nutrients that have a positive effect on human health. These products are called enriched or functional products. The production of such value-added products has also found a place in the poultry industry. Many scientists in their papers emphasize that designing poultry mixtures may affect the composition of omega- 3 fatty acids, various vitamins and minerals (Grčević et al., 2011; Imran et al., 2015; Kralik et al., 2016). In the world market, eggs enriched with omega-3 fatty acids, vitamin E, iodine, selenium and the like (Fisinin et al., 2009) can be bought.

Selenium was discovered by Swedish chemist Berzelius in 1818. At the time of its discovery, selenium was thought to be a very toxic element. However, in the middle of the 20th century, positive properties of selenium were determined (Ullrey, 1992). The role of selenium is very important because it is involved in regulating of various physiological functions in the body (Delezie et al., 2013). Selenium is a component of 25 selenoproteins and some enzymes such as glutathione peroxidase and thioredoxin reductase (Gajčević et al., 2009; Kralik et al., 2016). Furthermore, selenium is an important catalyst in the process of transforming the thyroid hormone from the inactive form (T4 thyroxine) into the active form (T3 triiodothyronine; Delezie et al., 2013). Selenium can have a positive effect on the reproduction and antioxidative defense of cells ( $\mathrm{Su}$ rai 2000; Yoon et al., 2007; Waseem et al., 2016). The aim of this paper was to present the possibilities of enriching the poultry products (meat and eggs) with selenium and pointing to the health effects of these products if used in human nutrition.

\section{SOURCES OF SELENIUM}

In the food chain, the basic source of selenium for animals are plants. Plants get selenium from the soil. Therefore, soil supply with this microelement is important. As the plant's supply of selenium depends on its availability in the soil, plants from different areas have different selenium content. Since the poultry mixtures are made from grains grown on different fields, the content of selenium is not uniform. If inorganic fertilizers containing sulfur are used in agriculture, the selenium availability for plant is reduced. Also, acidification of soil significantly reduces the availability of selenium for plants. Scientists have pointed out in the results of their research that an organic form of selenium produced in the form of selenium-based yeast is introduced as an addition to the animal mixture instead of the inorganic form of selenium (Surai, 2006; Kralik et al., 2009; Waseem et al., 2016). More recently, in crop production biofortification of cereals with selenium is carried out in order to increase the availability of this microelement to plants, and feeding the animals with mixtures in which these grains are used would increase the content of selenium in the products (Hassan, 1999; Haug et al. 2008; Kralik et al., 2016).

\section{ENRICHMENT OF POULTRY PRODUCTS WITH SELENIUM}

Scientists say that the source of selenium (inorganic-sodium selenite or organic-selenomethionine in the form of yeasts or algae) used in animal feed significantly influences its utilization in the body (Hess et al., 2000; Payne and Southern, 2005; Kralik et al. 2016) suggest that the increase of the selenium content in the mixtures $(0.15 \mathrm{mg} / \mathrm{kg}, 0.30$ $\mathrm{mg} / \mathrm{kg}$ and $0.50 \mathrm{mg} / \mathrm{kg}$ of the mixture) for laying hens has a statistically significant $(\mathrm{P}<0.001)$ effect on the increase of selenium content in egg whites (A $=0.052 \mathrm{mg} / \mathrm{kg}, \mathrm{B}=0.149 \mathrm{mg} / \mathrm{kg}$ and $\mathrm{C}=0.209$ $\mathrm{mg} / \mathrm{kg})$ and yolks $(\mathrm{A}=0.387 \mathrm{mg} / \mathrm{kg}, \mathrm{B}=0.663$ $\mathrm{mg} / \mathrm{kg}$ and $\mathrm{C}=0.863 \mathrm{mg} / \mathrm{kg}$ ). The influence of the selenium source $(P<0.05)$ on its content in eggs was determined by Waseem et al. (2016). They found that a group of hens that consumed feed without the addition of selenium has a statistically significantly lower selenium content in the whole egg $(7.77 \mu \mathrm{g})$ compared to eggs from hens that received inorganic selenium in the feed in an amount of 0.3 $\mathrm{mg} / \mathrm{kg}(9.14 \mu \mathrm{g})$. The highest content of selenium was found in eggs of hens that consumed feed with $0.3 \mathrm{mg} / \mathrm{kg}$ of organic selenium $(11.70 \mu \mathrm{g})$. Gajčević et al. (2009) and Bennett and Cheng (2010) also found that increasing selenium levels in hens' mixtures affects the increase of selenium content in eggs. Arpášová et al. (2009) indicate that egg quality was better in hens fed with organic form of selenium. In experimental groups where hens consumed mixtures with organic selenium $0.1 \mathrm{mg} / \mathrm{kg}$ of dry 
matter (A), $0.5 \mathrm{mg} / \mathrm{kg}$ of dry matter (B) and 0.9 $\mathrm{mg} / \mathrm{kg}$ of dry matter (C) they determined better quality of egg whites. In these groups $\mathrm{HU}$ values increased from $58.53 \mathrm{HJ}$ (A) to $87.01 \mathrm{HJ}$ (B) and 87.11 HJ (C). Pappas et al. (2005) and Gajčević et al. (2009) also point to a positive correlation between organic Se in feed for laying hens and the value of HU in eggs. Ševčíková et al. (2006), for chickens fed mixtures without the addition of organic selenium (A) and supplemented with 0.3 $\mathrm{mg} / \mathrm{kg}$ of selenium in form of selenium yeast, state that the level of selenium in feed has an effect on its content in meat of breasts and thighs. The selenium content in the breast increased from $52.11 \mu \mathrm{g} / \mathrm{kg}$ to $217.39 \mu \mathrm{g} / \mathrm{kg}$, and in thighs from $70.95 \mu \mathrm{g} / \mathrm{kg}$ to $247.87 \mu \mathrm{g} / \mathrm{kg}$. Gajčević (2011) states that the increase in the selenium level, in combination with linseed oil in mixtures for chickens affects the better deposition of selenium in breast muscles $(\mathrm{P}<$ 0.027). In the experiment, the author had a group $P 2$ in which $6 \%$ of linseed oil was added to the feed without the addition of organic selenium, $\mathrm{P} 4$ with $6 \%$ linseed oil and $0.3 \mathrm{mg} \mathrm{Se} / \mathrm{kg}$ feed and P6 group with $6 \%$ linseed oil and $0.5 \mathrm{mg} \mathrm{Se} / \mathrm{kg}$ feed. There was determined $0.090 \mathrm{mg} \mathrm{Se} / \mathrm{kg}$ of breast muscle tissue in P2, $0.191 \mathrm{mg} \mathrm{Se} / \mathrm{kg}$ breast in P4 and 0.321 $\mathrm{mg} \mathrm{Se} / \mathrm{kg}$ breast in P6. Mikulski et al. (2009) in the study of the influence of selenium source in feed for turkeys on quality and content of selenium in meat indicate that the source of selenium has an effect on the quality and content of selenium in meat $(\mathrm{P}<$ 0.05 ). Three groups of turkeys were used in the experiment: $\mathrm{A}=$ without the addition of selenium to feed, $\mathrm{B}=$ with $0.3 \mathrm{mg} / \mathrm{kg}$ inorganic selenium and $\mathrm{C}$ $=$ with $0.3 \mathrm{mg} / \mathrm{kg}$ organic selenium. In the results the authors state that selenium content was $\mathrm{A}=0.160$ $\mathrm{mg} / \mathrm{kg}, \mathrm{B}=0.224 \mathrm{mg} / \mathrm{kg}$ and $\mathrm{C}=0.468 \mathrm{mg} / \mathrm{kg}$ of turkey breast muscle. The authors point out the influence of selenium sources on better values of some meat quality parameters (cooking loss $\mathrm{A}=$ $14.38 \%, \mathrm{~B}=14.43 \%$ and $\mathrm{C}=13.63 \%$, drip loss on raw meat measured 24 hours post mortem $\mathrm{A}=$ $0.95 \%, \mathrm{~B}=0.94 \%$ and $\mathrm{C}=0.82 \%$ ).

\section{HEALTH EFFECTS OF SELENIUM}

Selenium is one of the important trace elements required for the normal functioning of a living organism. If there is deficit of any micro- or macroelement in the body, health can be disturbed and serious disorders or illness may arise. It is well known the occurrence of Keshan (endemic cardiomyopathy) and Kashin-Beck (endemic osteochon- dropathy) diseases due to low selenium status in human population as a result of selenium-deficient soil especially in northeastern to southwestern China (Combs and Combs, 1986). Selenium concentration in tissues, plasma or serum depends on intake and varies by country, and is generally lower in Eastern Europe compared to North America (Rayman, 2012). Selenium in the body is a part of selenoproteins that have a wide range of health benefits. Most important of them are glutathione peroxidases (GPxs), thioredoxin reductases (TrxR) andiodothyronine deiodinases. They show antioxidant and antiinflammatory effects and are included in the production of active thyroid hormone (Rayman, 2012). One of the most important health benefit of selenium is its role in cancer prevention. Duffield-Lillico et al. (2002) showed that treatment with $200 \mu \mathrm{g}$ selenium per day (as selenium yeast) for a mean of 4.5 years resulted in a significant reduction in cancer mortality $(50 \%)$ and in the incidence of total $(37 \%)$, prostate $(67 \%)$, colorectal $(58 \%)$, and lung (46\%) cancers after a follow-up of 6.4 years. Low selenium status is associated with poor immune function. Selenium supplementation enhances proliferation of activated T cells and increase total Tcell count, hence boosting immune response (Rayman, 2000). Selenium is also very important to human fertility and reproduction. It is shown that glutathione peroxidase GPx 4 protects spermatozoa by its antioxidant function and with other proteins forms structural component of the flagellum which is essential for sperm motility (Ursini et al., 1999). Low selenium status was connected with pre-eclampsia (Rayman et al., 2003) and preterm birth (Rayman et al., 2011) in women. At the end, it is important to note that additional selenium intake may benefit people with low selenium status while those who have adequate or high status should be careful and not take selenium supplements since it may have adverse effect (Rayman, 2012).

\section{CONCLUSION}

People are increasingly taking care of their health, so they take more care about their daily nutrition. Since the consciousness of people about their own health has been emphasized for a decade now, there are more and more value-added products in the market, so called enriched or functional products. Production of poultry products enriched with selenium is of great importance for manufacturing and food sector. By introducing new technologies in poultry production it is possible to produce meat and 
eggs with increased selenium content, which can be marketed as new products on the market of food products.

Acknowledgment: The research necessary for this paper is part of the project "Enriching of „Hrvatica“ hen eggs with essential microelements" funded by Ministry of Agriculture (The Council for Agriculture ResearchVIP).

\section{REFERENCES}

[1] Arpášová, H., Mellen, M., Kačániová, M., Haščík, P., Petrovič, V., Čobanová, K., Leng, L.: Effects of dietary supplementation of sodium selenite and selenized yeast on selected qualitative parameters of laying hens eggs. Slovak J. Anim. Sci., 42 (1): 27-33 (2009).

[2] Bennett, D. C., Cheng, K. M.: Selenium enrichment of table eggs. Poultry Science, 89, 2166-2172 (2010.).

[3] Combs, G. F. and Combs, S. B., eds.: The Role of Selenium in Nutrition. New York: Academic Press, 1986.

[4] Delezie, E., Segers, L., A. Van Der, Aa. A., Wittocx, S., Maertens, L.: Efficacy of Se influenced by source and inclusion level and effect on Se egg's concentration. World's Poultry Science Journal, Vol. 69, Supplement. Egg Meat Symposia, Bergamo, 15-19 September 2013.

[5] Duffield-Lillico, A. J., Reid, M. E., Turnbull, B. W. et al.: Baseline characteristics and the effect of selenium supplementation on cancer incidence in a randomized clinical trial: A summary report of the Nutritional Prevention of Cancer Trial. Cancer Epidemiol Biomarkers Prev, 11, 630-639 (2002)

[6] Gajčević, Z.: Utjecaj selena i lanenog ulja u hrani na performance pilića i profil masnih kiselina u mišićnom tkivu. Doktorska disertacija, Poljoprivredni fakultet u Osijeku, Osijek, 2011.

[7] Gajčević, Z., Kralik, G., Has-Schön, E., Pavić, V.: Effects of organic selenium supplemented to layer diet on table egg freshness and selenium content. Italian Journal of Animal Science, 8 (2), 189-199 (2009).

[8] Hassan, S.: Influence of dietary sodium selenite and barley selenium on the performance of laying hens and their subsequent progeny. Acta Agriculturae Scandinavica. 40, 267-278 (1990).

[9] Haug, A., Eich-Greatorex, S., Bernhoft, A., Hetland, H., Sogn T.: Selenium bioavailability in chicken fed seleniumfertilized wheat. Acta Agriculturae Scandinavica A.58 (2): 65-70 (2008).

[10] Hess, J. B., Dows, K. M., Bilgili, S. F.: Selenium nutrition and poultry meat quality. Poult. Sci. 79, 107-112 (2000.).

[11] Imran, M., Anjum, F. M.,Nadeem, M., Ahmad, N., Khan, M. K., Mushtaq, Z., Hussain, S.: Production of Bio-omega3 eggs through the supplementation of extruded flaxseed meal in hen diet. Lipids in Health and Disease. 14, 25-9 (2015).

[12] Kralik G., Gajčević Z., P. Suchý, E. Straková, Hanžek D.: Effect of dietary selenium source and storage on internal quality of eggs. Acta Veterinaria Brno, 78, 219-222 (2009).

[13] Kralik Z., Grčević M., Radišić Ž., Kralik I., Lončarić Z., Škrtić Z.. Effect of selenium-fortified wheat in feed for laying hens on table eggs quality. Bulgarian Journal of Animal Science. 2 (22), 297-302 (2016a).

[14] Kralik, Z., Kralik, G., Grčević, M.: Increase of selenium content in table eggs. Proceedings of the International Symposium on Animal Science, Prof. Dr Zoran Popović (ur.). Belgrade: University of Belgrade, Faculty of Agriculture, Nemanjina 6, 11080 Belgrade-Zemun, Serbija, 2016b, pp. 535-540, ISBN: 978-86-7834-261-5.

[15] Mikulski, D., Jankowski, J., Zduńczyk , Z., Wróblewska, M., Sartowska K., Majewska, T.: The effect of selenium source on performance, carcass traits, oxidative status of the organism, and meat quality of turkeys. Journal of Animal and Feed Sciences. 18, 518-530 (2009).

[16] Pappas, A. C., Acamovic, T., Sparks, N. H. C., Surai, P. F., Mcdevitt, R. M.: Effects of supplementing broiler breeder diets with organic Se and polyunsaturated fatty acids on egg quality during storage. Poultry Science. 84, 865-874 (2005).

[17] Payne, R. L., Southern, L. L.: Comparison of inorganic and organic selenium sources for broilers. Poultry Sci. 84, 898-902 (2005).

[18] Rayman, M. P.: Selenium and human health. Lancet, 379, 1256-1268 (2012).

[19] Rayman, M. P.: The importance of selenium to human health. Lancet, 356, 233-41 (2002).

[20] Rayman, M. P., Bode, P., Redman, C. W.: Low selenium status is associated with the occurrence of the pregnancy disease preeclampsia in women from the United Kingdom. Am J Obstet Gynecol, 189, 1343-49 (2003).

[21] Rayman, M. P., Wijnen, H., Vader, H., Kooistra, L., Pop, V.: Maternal selenium levels during early gestation and risk for preterm birth. CMAJ, 183, 549-55 (2011).

[22] Ševčíková, S., Skřivan, M. Dlouhá, G., Koucký, M.: The effect of selenium source on the performance and meat quality of broiler chickens. Czech J. Anim. Sci. 51 (10), 449-457 (2006).

[23] Surai, P. F.: Selenium in nutrition and health. Nottingham University Press, Nottingham, UK, 2006, pp. 32-168.

[24] Ullrey D. E.: Basis for regulation of selenium supplements in animal diets. Journal of Animal Science, 70, 3922-3927 (1992).

[25] Ursini, F., Heim, S., Kiess, M., et al.: Dual function of the selenoprotein PHGPx during sperm maturation. Science, 285, 1393-96 (1999).

[26] Waseem, M. Z., Anjum, K., Saima, N., Jibran, H., Muhammad, I., Tahir, M. K., Shafique, M. R.: Exploring the effect of selenium forms on final body weight, slaughter characteristics and tissue selenium concentration in Aseel cockerels. Indian J Anim Res. (2016), DOI:10.18805/ijar.10764.

[27] Yoon, I., Werner, T., Butler, J.: Effect of source and concentration of Se on growth performance and Se retention in broiler chickens. Poultry Science. 86, 727-730 (2007). 